\title{
GEOELECTRICAL PROSPECTION OF DISSEMINATED SULFIDE MINERAL OCCURRENCES IN CAMAQUÃ SEDIMENTARY BASIN, RIO GRANDE DO SUL STATE, BRAZIL
}

\author{
César Augusto Moreira ${ }^{1}$, Syngra Machado Lopes², Camila Schweig² and Adriano da Rosa Seixas² \\ Recebido em $1^{\circ}$ abril, 2011 / Aceito em 28 março, 2012 \\ Received on April 1, 2011 / Accepted on March 28, 2012
}

\begin{abstract}
The mineral exploration is a complex activity that should involve a combination of direct and indirect techniques of geological investigation. The growing demand for base metals in the national and international market provides the revaluation of mineral occurrences that can become deposits and mines. This paper presents the results of the electrical resistivity and induced polarization geophysical methods in azimuthal arrangement, applied in a mineral occurrence of disseminated copper sulfides, previously studied through trenches and core drilling, located in the Camaquã Sedimentary Basin, Rio Grande do Sul State, Brazil. The inversion models indicate the coincidence of high chargeability and low resistivity values. The integration of geophysical data permitted the elaboration of 3D attributes visualization models for the mineralization enclosed in volcanic tuffs. The integrated geophysical and geological analysis indicates the potential of a new mineralized area.
\end{abstract}

Keywords: ore, sulfide, copper, geophysics, modeling.

RESUMO. A pesquisa mineral é uma atividade complexa, que deve envolver preferencialmente a combinação de técnicas diretas e indiretas de investigação geológica. A demanda crescente por metais base no mercado nacional e internacional proporcionam a reavaliação de ocorrências minerais, que podem ser convertidas em depósitos e minas. Este trabalho apresenta os resultados da aplicação dos métodos geofísicos de eletrorresistividade e da polarização induzida em arranjo azimutal, numa ocorrência mineral de sulfetos de cobre disseminados, previamente estudada por meio de trincheiras e sondagem testemunhada, localizada na Bacia Sedimentar do Camaquã, Estado do Rio Grande do Sul. Os modelos de inversão indicam o predomínio de alta cargabilidade coincidente com valores de baixa resistividade. A integração dos dados geofísicos possibilitou a elaboração de modelos de visualização 3D para análises dos atributos associados à mineralização, alojada em tufos vulcânicos. A análise integrada de dados geofísicos e geológicos aponta para uma região potencialmente mineralizada.

Palavras-chave: minério, sulfeto, cobre, geofísica, modelagem.

\footnotetext{
${ }_{1}$ Assistant Professor, Department of Applied Geology (DGA), Instituto de Geociências e Ciências Exatas (IGCE), UNESP - Universidade Estadual Paulista, Av. 24A, 1515, Bela Vista, Caixa Postal 178, 13506-900 Rio Claro, SP, Brazil. Phone: +55 (19) 3526-9313 - E-mail: moreirac@rc.unesp.br

2 Postgraduate students in Regional Geology - IGCE/UNESP, Av. 24A, 1515, Bela Vista, Caixa Postal 178, 13506-900 Rio Claro, SP, Brazil. Phone: +55 (19) 3526-2802

- E-mails: syngralopes@gmail.com; camilabarz@hotmail.com; adriano.seixas83@gmail.com
} 


\section{INTRODUCTION}

The increasing demand and the low availability of base metals stimulated the creation or improvement of new mineral surveys techniques. The main stages or procedures used in the mineral surveys are: geologic characterization, geochemistry and geophysics (Peters, 1978; Maranhão, 1985; Pereira, 2003).

The geologic characterization consists in the field analysis of rock outcrops, mineral occurrences, samples from trenches and drill cores. The geochemical surveys consist in the analysis of various types of material such as: fluvial sediments, pan concentrates, soils, whole-rock, surface and underground waters, besides vegetation. The purpose is the detection of areas with an increase or a decrease of chemical elements which, directly or indirectly may indicate the presence of mineral concentrations which are economically viable.

During mineral prospection, the geophysical methods present the possibility of performing rapid regional surveys with lower costs in comparison with the direct methods. The geophysical methods used in mineral surveys may involve airborne acquisitions such as magnetometry, gamma-spectrometry and gravimetry, besides land acquisitions with gravimetry, gammaspectrometry, magnetometry, seismic, electromagnetic, electric and remote sensing.

The search for base metals, such as copper is linked to the national and international consumer market demand. The increasing need of these important inputs for metallurgy, steel metallurgy, pharmaceutics, among others, rises the interest for the exploration of marginal mineralized areas with lower ore contents and volumes, since the discoveries of major mineral deposits are very unexpected.

The present work presents geophysical data acquired in one of the various mineral occurrences of disseminated copper sulfides, located in the Camaquã Sedimentary Basin, Rio Grande do Sul State, Brazil. The geologic context of this basin is marked by its complexity, with a stratigraphic record which includes sedimentary rocks from marine, alluvial and eolian origin, as well as volcanoclastic rocks with a varied composition (Borba, 2006).

The selection of the study area was based on the availability of surface geochemistry data and a core description, both made in 1965 by the Brazilian Geological Survey (Departamento Nacional de Produção Mineral - DNPM) (Bocchi, 1965). These data allowed the recognition of a mineral occurrence of copper, without economic interest for mining due to the small volume and ore content.

The present work presents the results of electrical resistivity and induced polarization data analysis integrated with direct samples information, with the purpose to reevaluate the ore potential of the site.

\section{AREA LOCATION AND HISTORY}

The study area is located at $12 \mathrm{~km}$ from the city of Caçapava do Sul, distant $259 \mathrm{~km}$ from the capital city of Porto Alegre, approximately $12 \mathrm{~km}$ to the SW of the intersection of highways BR 290 and BR 392 in Rio Grande do Sul State. The coordinates of the center of the study area are $30^{\circ} 25^{\prime} 17^{\prime \prime} \mathrm{S}$ and $53^{\circ} 31^{\prime} 57^{\prime \prime} \mathrm{W}$ where the arrangement for the geophysical data acquisition was centered (Fig. 1)

Caçapava do Sul region is historically known for its mining activities, which go back to the XIX century, mainly for copper and gold, up to the 1990-decade (Ronchi \& Lobato, 2000). During this period a significant decrease of metal prices occurred in the international market, causing the interruption of various mines, including, among others, the Camaquã Mine, which extracted copper for over 70 years. Presently the mining activities in the county are restricted to the extraction of limestone.

The copper occurrence within the study area was named Colônia Santa Bárbara, and was prospected by the Brazilian Geological Survey (DNPM) (Bocchi, 1965). The prospection works were initiated with the opening of three trenches, with sampling at each meter, for ten meters. Copper content was lesser than $1 \%$ for the richest sample analyzed cores, from one well drilled with a $60^{\circ}$ dip in the direction $N^{\circ} 120$, revealed the presence of chloritic zones and sulfide levels with pyrite (Fig. 2).

The mineralization indicative minerals are barite, quartz and calcite in joints and in the brecciated zone and siderite at the surface. However, the concentration of copper is minimal (Bocchi, 1965). The visible copper on surface, possibly resulted from a supergene concentration, with surficial minerals represented by malachite and secondary chalcosite in horizontal levels, in the upper soil horizons.

\section{GEOLOGY}

The study region is inserted in the Camaquã Basin, located over the Sul-Rio-Grandense Shield, including sedimentary units from 450-620 My (Paim et al., 2000). This basin evolved as a superposition of different basins individualized by its tectonics, geochronology and thermodynamic. Its evolution is related to the final phases of the tectonics of the Brazilian Orogeny (Chemale Jr., 2000; Paim et al., 2000).

Large sedimentary rates and subsidence characterizes the basin, with thick sedimentary and volcanoclastic packages intercalated by distinct erosional intervals. The siliciclastic intervals are intercalated by large volcanic layers, mainly at the base of the higher hierarchy units. The basin is strongly affected by 


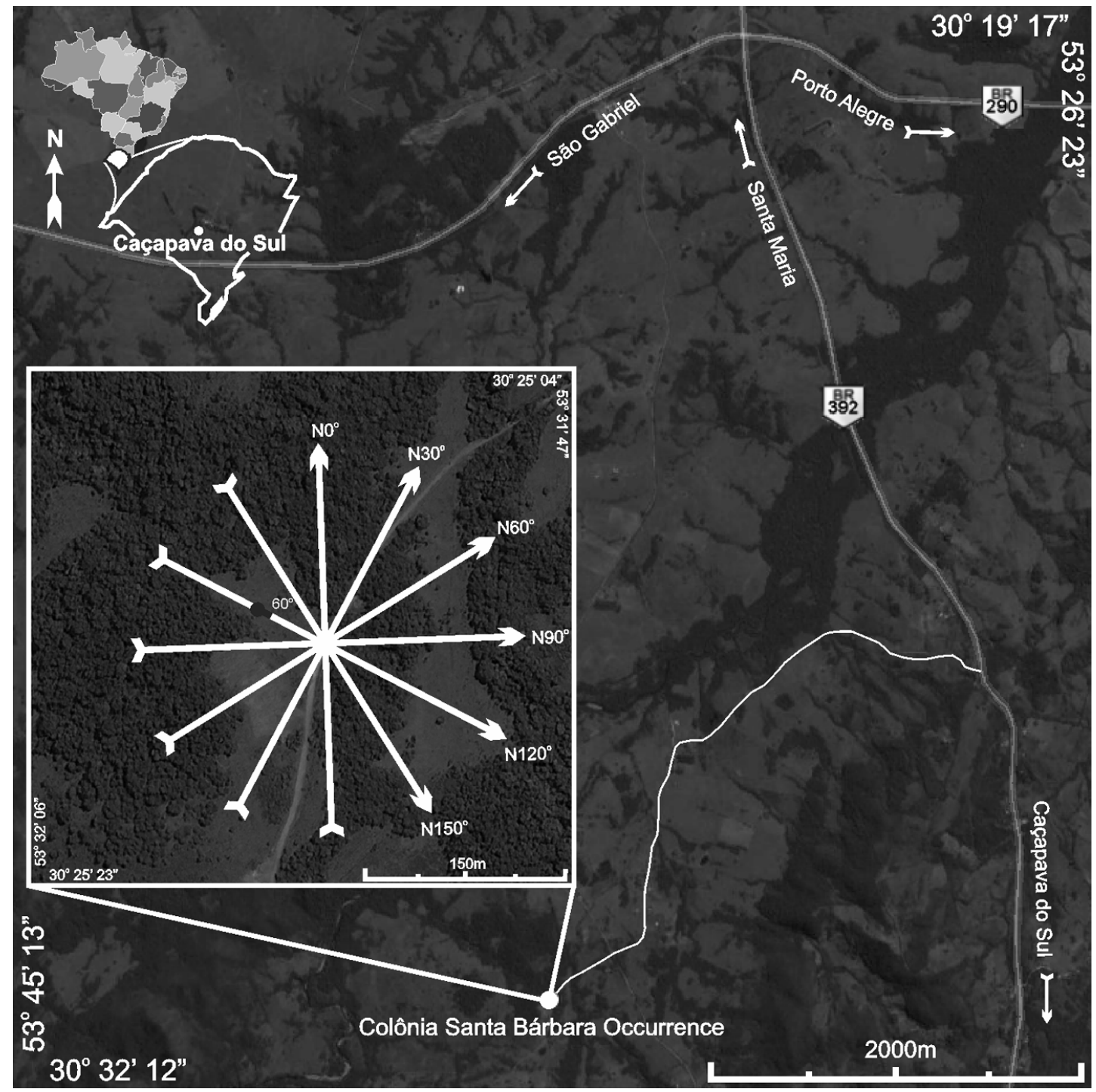

Figure 1 - Location of the study area, with the acquisition lines arrangement and the position and dip information of the well.

deformation events generating a complex filling pattern (Kazmierczak, 2006).

Lithotypes belonging to the Vacacaí Metamorphic Complex and volcanic and volcanoclastic sequences from the Bom Jardim Group, represented by the Hilário Formation are recognized in the study area (Fig. 3).

The Vacacaí Metamorphic Complex incorporates the volcanosedimentary and the meta-volcanic units, and constitutes the basement of this sedimentary basin. The regional metamorphism which affected the rocks of this association is of low degree, having rocks with a higher metamorphic degree only in the vicinities of granite intrusions, where a mineral paragenesis occurs with cornubianite hornblende facies (Ribeiro, 1970). A regional meta- morphism zoning was defined for the whole basin, which varies from the chlorite zone, widely dominant, to the staurolite zone (Ribeiro \& Fantinel, 1978).

The meta-volcano-sedimentary unit is mainly constituted by pelitic rocks with subordinated occurrences of thin sand layers and eventual ortho-derivated rocks (Porcher, 1995). The meta-pelitic rocks present dark grey and greenish grey colors, with alternations of light and dark millimeter bands. The metavolcanic rocks are predominantly tuffaceous rocks and, subordinated volcanics, to which epiclastic lithologies are associated. The meta-volcano-clastic lithotypes, are classified as tuffs, lapilli tuffs, powder tuffs, flows and epiclastic deposits, based on the grain size of the fragments. 


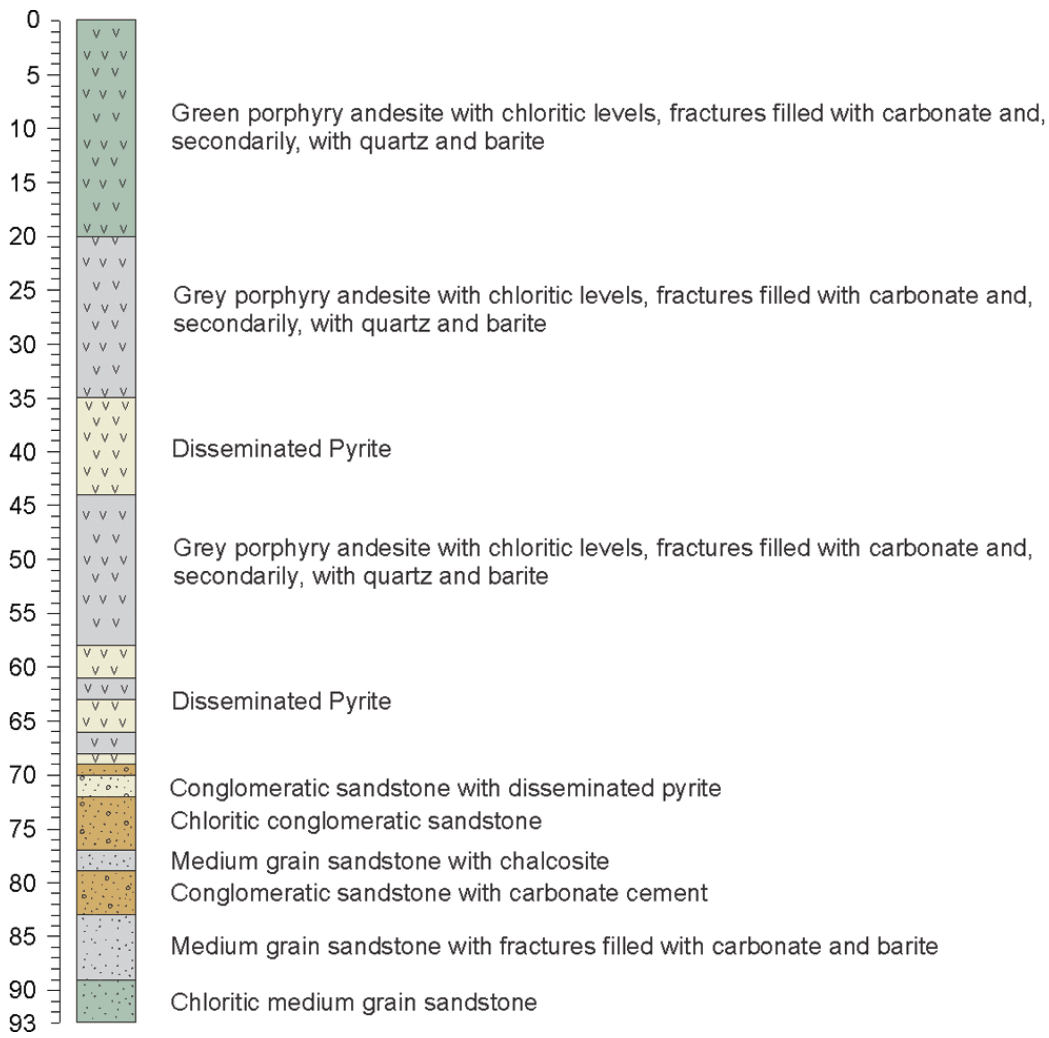

Figure 2 - Well description (Schweig, 2010).

The Bom Jardim Group represents a volcanic event covering the siliciclastic rocks of the Maricá Group. The Hilário Formation belongs to this group and includes an extensive andesitic volcanism with flows, tuffs and breccia, volcanic conglomerates, mudflows, greywackes, dikes, intrusive maffic rocks and locally, dacitic rocks on the top of the sequence (Porcher \& Lopes, 2000). This formation groups all deposits of volcanic nature, including flows, sub-volcanic rocks or volcano-clastics, either of pyroclastic nature or epiclastics related to the neo-proterozoic ( $~ 592 \mathrm{My}$ ), intermediate to basic magmatism with shoshonitic affinity (Nardi \& Lima, 1985).

The andesites occur as flows and dikes, with dark grey to greenish grey colors, eventually dark red or reddish, porphyritic, with feldspar phenocrysts, hornblende and locally fine barite, malachite and carbonate veins. The basalt flows or dikes are dark grey and black, showing porphyritic texture with pyroxene and plagioclase phenocrysts immersed in a fine-grained matrix (Porcher, 1995).

Meta-conglomerates and localized reddish conglomeratic sandstones are the lithotypes representing the metamorphic complex. The conglomerate clasts are rounded quartz pebbles and granitic rocks.
The volcanic lithotypes from Hilário Formation are represented by exposures of volcanic tuffs, presented as rounded fragments within a volcanic ash fine matrix (Porcher, 1995). Strongly fractured andesites also occur, being rich in quartz, carbonates and barite veins. Greenish spots of malachite occur in both lithotypes.

Local geophysical and structural analyses (Schweig, 2010) suggest that the mineralization has a strong structural control, OCcurring at the intersection of orthogonal fault planes, with directions $\mathrm{N}^{\circ} 0^{\circ}$ and $\mathrm{N} 150^{\circ}$. The structural control is also suggested by the volcanic tuff and andesitic fault blocks elevated, in relation to the meta-conglomerate.

\section{MATERIALS AND METHODS}

Electrical resistivity and induced polarization methods were used to measure the electrical resistivity and the chargeability. The theoretical principles of these methods, physical properties of the geologic materials pertinent to the methods, as well as the physical phenomena involved, are detailed by Orellana (1972); Sumner (1976) and Telford et al. (1990).

This work used a Wenner-Schlumberger arrangement with electrodes spacing of $15 \mathrm{~m}$. The electrical resistivity and charge- 


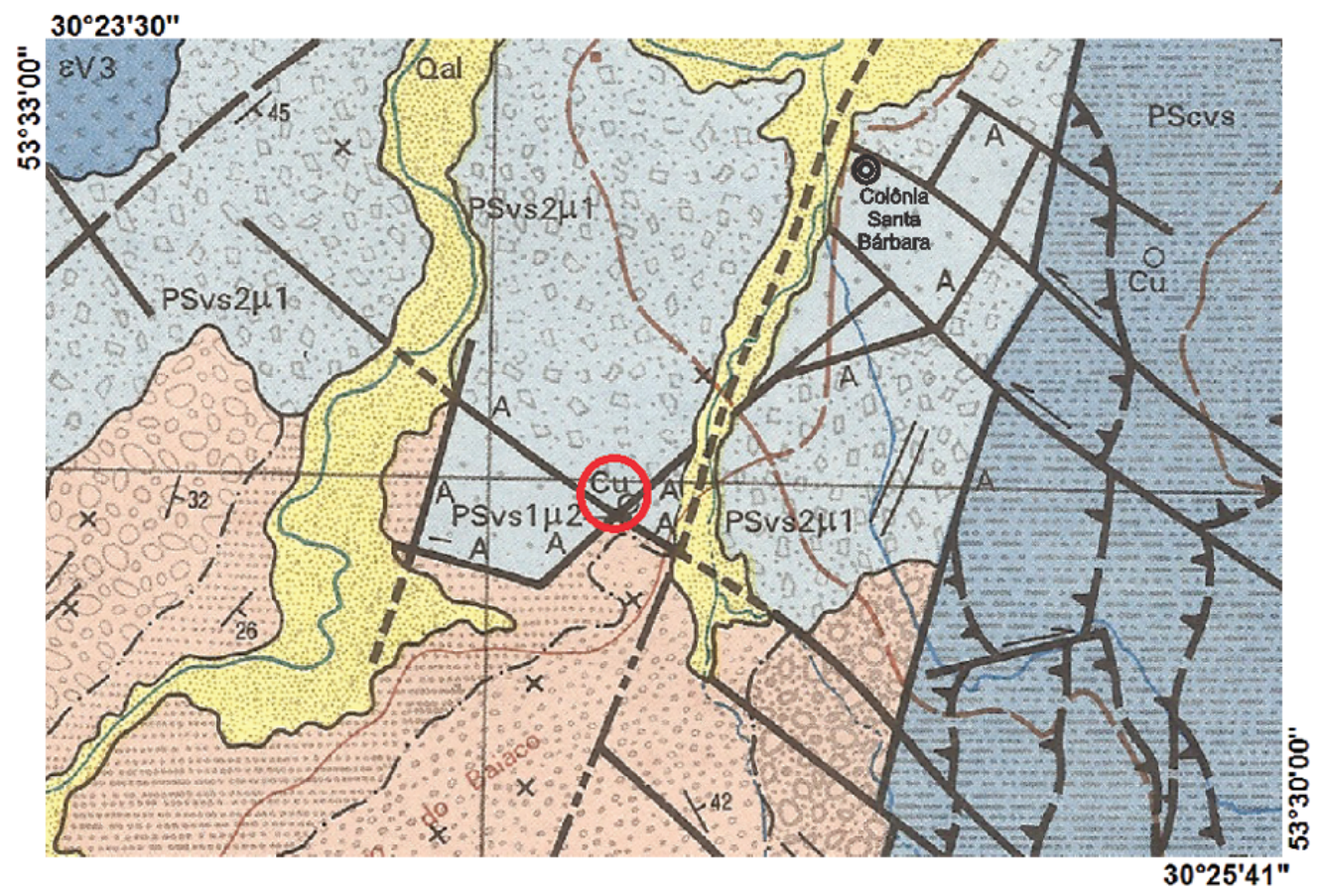

\section{Cartographic Conventions}

$\cup$ Drainage

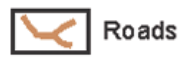

(0) Village

Colônia Santa Bárbara Occurrence

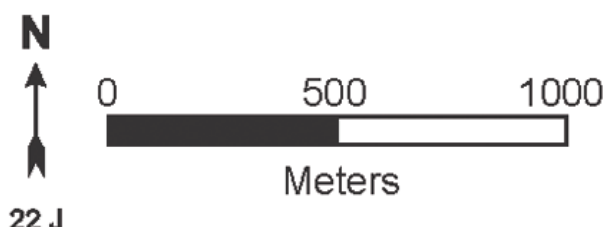

\section{Geological Conventions}

Alluvial Deposits (Quaternary)

Gravel, arenites, siltites and argilites

Hilário Formation (Neoproterozoic)

Andesites, volcanic breccies, basalts e dacites

Volcanic tuffs, from lapilli to powder

\section{Vacacaí Metassedimentary Sequence (Neoproterozoic)}

1. Metarenite fine, metaconglomerate polymictic, arkose

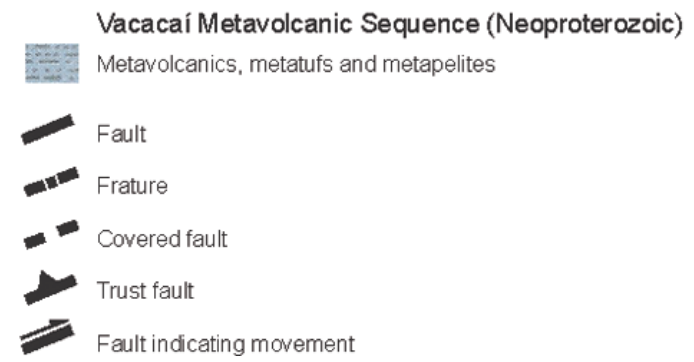

Figure 3 - Geologic map of the study area (Adapted from Porcher, 1995).

ability readings were recorded for 10 depth levels along 6 electric survey lines measuring $380 \mathrm{~m}$ length each, adding to a total of $2,880 \mathrm{~m}$ of acquisition. The lines were arranged in an azimuth form, with the central point fixed over the mineral occurrence, and an angular interval of $30^{\circ}$ (Fig. 1).

A Syscal Pro resistivity meter was used, with $250 \mathrm{~W}$ power, maximum transmission current of $2.5 \mathrm{~A}$ and resolution of $1 \mu \mathrm{V}$, allowing chargeability readings in $\mathrm{mV} N$. This equipment is cal- ibrated for resistivity and chargeability readings by means of periodic cycles of alternate low frequency electric current which allows to filter the noises of the acquired signal. The following calibration parameters for chargeability readings were applied: tension of $400 \mathrm{~V}$, reading period of 2,000 ms and reading window of $80 \mathrm{~ms}$.

The data were processed with the RES2DINV software (Loke \& Barker, 1996), and visualized as electrical resistivity sections. 
The inversion process consists in a series of rectangular blocks, in which the disposition of the blocks is connected to the distribution of the field points in the pseudosection, which is the section generated by the field data in theoretical depth. The depth of the lower line of the blocks is defined to be approximately equal to the equivalent investigation depth of the points with greatest space among electrodes (Edwards, 1977).

The direct modeling sub-routine is used to calculate the apparent resistivity values, and a minimum squares non-linear optimization technique is used for the inversion routine (DeGrootHedlin \& Constable, 1990; Loke \& Barker, 1996). The result is presented as a distance versus depth sections for the pseudosection condition, calculated section and inversion model. Only the inversion models, related to resistivity and chargeability are presented in this work.

The 3D visualization model was generated from previously 2D modeled data, using the Oasis montaj program developed by Geosoft.

This work adopts the method of minimum curvature for data interpolation. The interpolation consists in a mathematical process of adjustment of a function for points not-sampled, based in values obtained in sampled points. Using the sampled points a network is defined with a spacing related to the points. The value of each network node is calculated through the selection of the nearest known points, which are later filtered in order to soften the resulting contours and allow a better adjustment with the original values.

\section{PRESENTATION OF THE RESULTS}

The results are presented as resistivity and chargeability inversion models (Figs. 4 and 5). Since there was no significant reduction of the root mean square error (RMS) for models generated with more than 3 inversions, this number was adopted as the processing limit for both measured physical parameters.

The large variation of the resistivity values obtained in the inversion models basically reflects the range of measurements obtained in the field, in its majority obtained over metaconglomerates predominantly quartzoze. Although the scale of resistivity presents an ample variation between the minimum and maximum values, its adoption was based on the possibility to enhance the features pertaining to the discussion, interpretation and understanding of the geologic conditions associated to the mineral occurrence studied.

The inversion models present a relatively high RMS error, mainly in the N120WS section, being this fact attributed to the contrast between maximum and minimum values of the program input data.

The sections with a relatively low RMS error are characterized by plane-parallel horizons with resistivity increasing with depth. The section N120WS is the only exception to this pattern, characterized by the average of the lowest values and by low resistivity values at depth in the central portion. This abrupt lateral variation of values, from the center to the borders of the section, possibly contributed for an increase of the RMS error in this case.

The resistivity values along line $\mathrm{N}^{\circ}$ varies from $3225 \Omega . \mathrm{m}$ near the surface, up to $548096 \Omega$.m at $25 \mathrm{~m}$ depth. Between $260 \mathrm{~m}$ and $360 \mathrm{~m}$ occurs a local low resistivity zone, with minimum values of $11644 \Omega$.m from the surface down to $20 \mathrm{~m}$ depth. The line $N 30^{\circ}$ presents resistivity values from $11644 \Omega$.m near the surface, up to $548096 \Omega$.m below $30 \mathrm{~m}$ depth. The continuous increase in resistivity with depth indicates the presence of soil at surface, over non-weathered rock at depth (Fig. 4).

The line $\mathrm{N} 60^{\circ}$ presents moderate to high resistivity values, from $11644 \Omega . m$ to $151800 \Omega$.m along the first $30 \mathrm{~m}$ of investigation at surface. In general, the resistivity increases with depth, from $11644 \Omega . m$ to $548096 \Omega$.m. Nevertheless, there is an interval between $60 \mathrm{~m}$ and $110 \mathrm{~m}$ with a substantially lower resistivity with increasing depths, which apparently defines a low resistivity window (Fig. 4).

The line $\mathrm{N}^{\circ} 0^{\circ}$ presents resistivity values from moderate to high, which vary from $11644 \Omega$.m to $548096 \Omega$.m along the line. The increase of resistivity with depth is also observed (Fig. 4).

The line $\mathrm{N} 120^{\circ}$ presents horizontal layers up to approximately $30 \mathrm{~m}$ depth, with resistivity increase with depth and values between $3225 \Omega . m$ and $508096 \Omega$.m. The interval between $140 \mathrm{~m}$ and $200 \mathrm{~m}$ presents maximum values at depth of around $151800 \Omega$ S.m. The well adopted for the correlation with the geophysical data, was drilled near the position $160 \mathrm{~m}$ of this line (Fig. 2).

The line $\mathrm{N} 150^{\circ}$ presents horizontal resistivity layers, with values which increase gradually with depth, varying from $3225 \Omega$.m to $548096 \Omega$.m (Fig. 4).

The chargeability model for line $\mathrm{N}^{\circ}$ presents a great contrast between the initial portion, with values between $3.7 \mathrm{mV} / \mathrm{N}$ and $16 \mathrm{mV} / \mathrm{N}$, and the final portion, with values between $3.7 \mathrm{mV} / \mathrm{N}$ and $0.40 \mathrm{mV}$. The low resistivity interval described at the end of this section is characterized by high chargeability values (Fig. 5).

The chargeability model presents median slightly variable values in almost the entire line $\mathrm{N} 30^{\circ}$, between $7.8 \mathrm{mV} / \mathrm{N}$ and $34.5 \mathrm{mV}$. Between $60 \mathrm{~m}$ and $195 \mathrm{~m}$ predominate values between $3.7 \mathrm{mV} / \mathrm{N}$ and $16 \mathrm{mV} / \mathrm{N}$, followed by values between $16 \mathrm{mV} / \mathrm{N}$ 

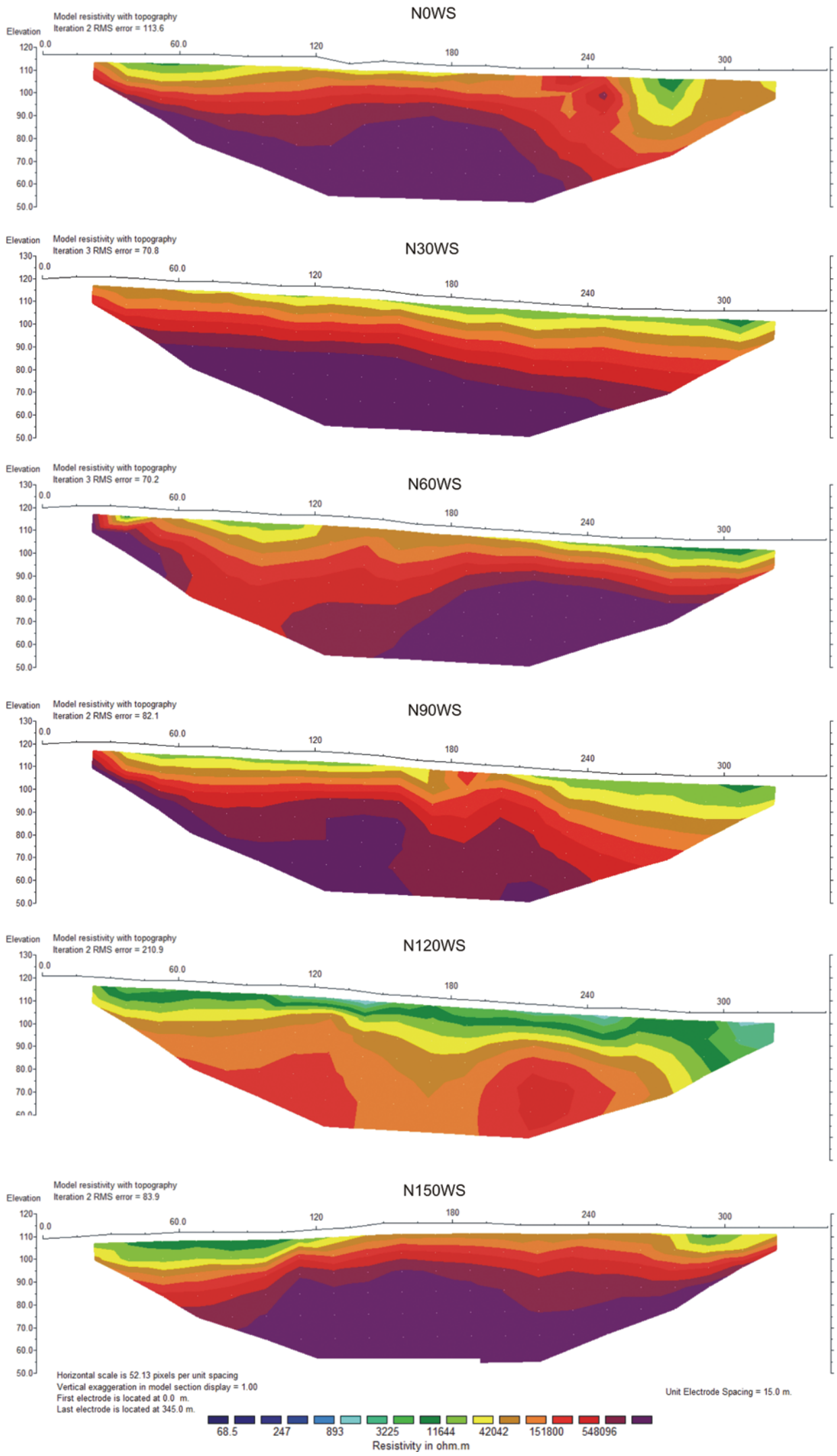

Figure 4 - Models of electrical resistivity inversion obtained after processing, with the scale of values in $\Omega$.m. 

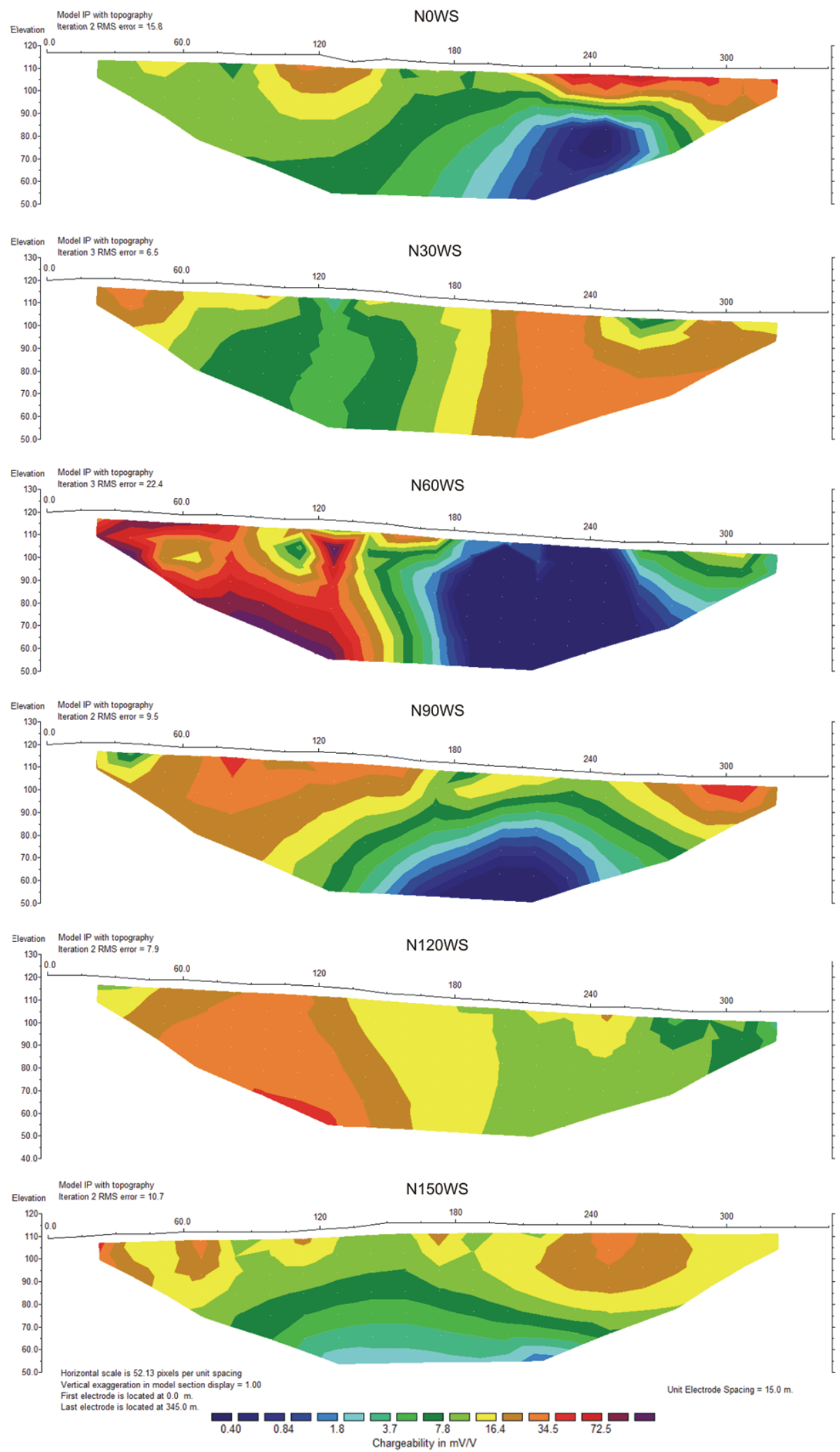

Figure 5 - Models of chargeability inversion obtained after processing, with the scale of values in mV/N. 


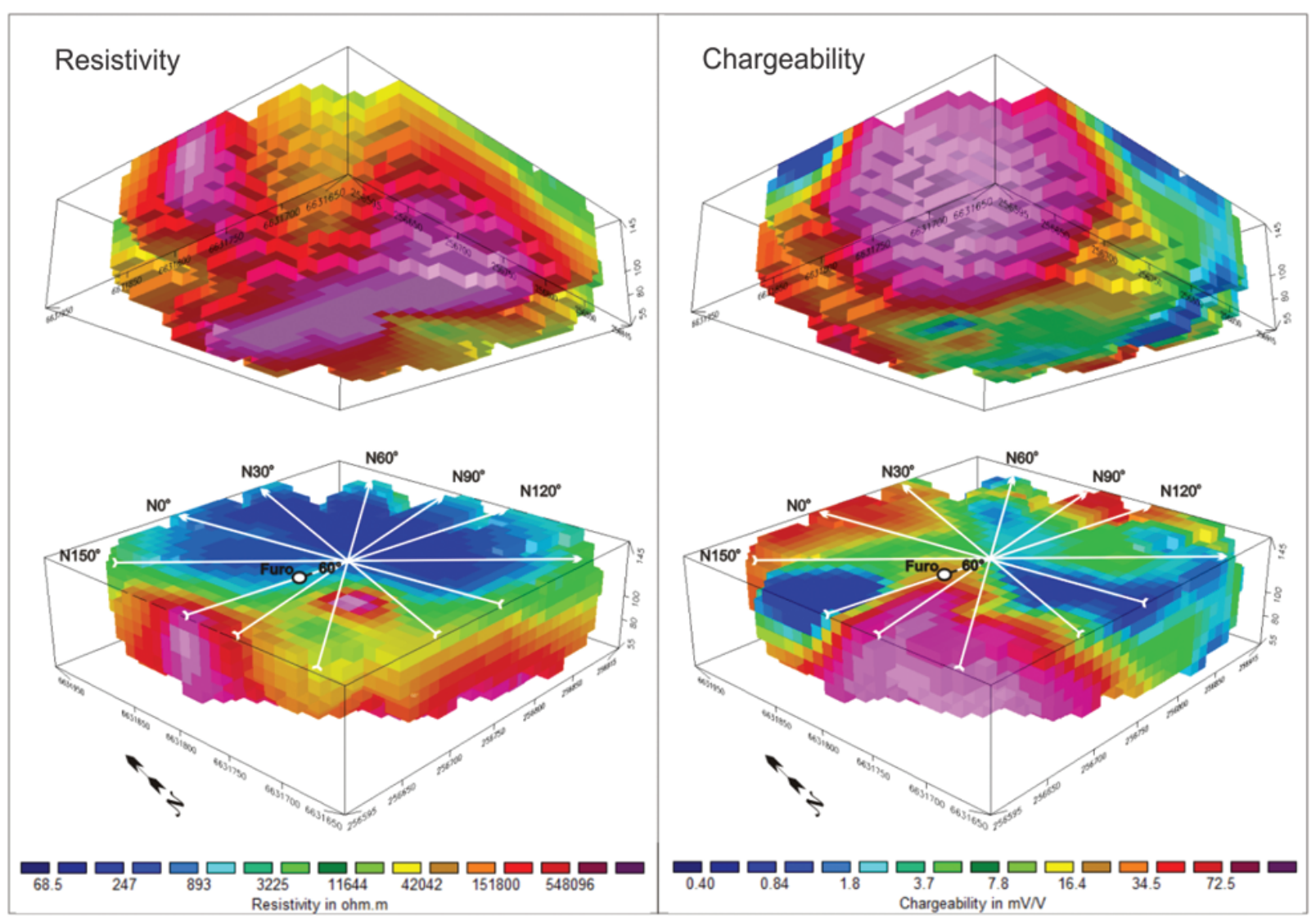

Figure $6-3 D$ resistivity and chargeability models, with an angle of view towards $N 40^{\circ}$, upper and lower view perspectives and location of the drilled well with dip and angle information.

and $34 \mathrm{mV} / \mathrm{N}$, between $0 \mathrm{~m}$ and $60 \mathrm{~m}$ and between $195 \mathrm{~m}$ and $345 \mathrm{~m}$. The interval between $120 \mathrm{~m}$ and $135 \mathrm{~m}$ presents a vertical strip of low chargeability, apparently not related with resistivity variations. It was possible to verify in the field that this line crosses volcanic tuffs between $0 \mathrm{~m}$ and $165 \mathrm{~m}$, followed by metaconglomerates to the end (Fig. 5).

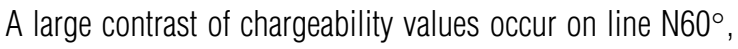
varying from $0.4 \mathrm{mV} / \mathrm{N}$ to $72.5 \mathrm{mV} / \mathrm{N}$. From $0 \mathrm{~m}$ to $160 \mathrm{~m}$ predominate values around $25 \mathrm{mV} / \mathrm{N}$, with the format of an inverted triangle. The interval between $160 \mathrm{~m}$ and the end of the section is marked by low chargeability values at depth (Fig. 5).

The chargeability values for line $\mathrm{N} 120^{\circ}$ decrease with depth, from approximately $16.4 \mathrm{mV} / \mathrm{N}$ in the surface to $1.8 \mathrm{mV} / \mathrm{N}$ at the base of the section. The chargeability values for line $\mathrm{N} 150^{\circ}$ also decrease with depth, from approximately $16.4 \mathrm{mV} / \mathrm{N}$ on the surface to extremely low chargeability values, around $1.8 \mathrm{mV} / \mathrm{N}$, at the base of the section (Fig. 5).

The modeled data for each line were georeferenced and gathered in only one spreadsheet for the generation of three- dimensional models, presented in color scales, where the high values are presented in hot colors (pink shades), while the low values are presented in cold colors (blue shades). The scale of values is the same adopted for the inversion models (Fig. 6). The $3 \mathrm{D}$ blocks present an angle of view near to $\mathrm{N} 40^{\circ}$, rotated for an aerial perspective view and for subsurface (Fig. 6).

The $3 \mathrm{D}$ visualization model presents high chargeability values between the $\mathrm{N}^{\circ} 0^{\circ}$ and $\mathrm{N}^{\circ} 0^{\circ}$ azimuths, with maxima around $72.5 \mathrm{mV} / \mathrm{N}$, predominantly at the beginning of lines $\mathrm{N} 30^{\circ}, \mathrm{N}_{60}{ }^{\circ}$ and $\mathrm{N} 90^{\circ}$, in the SW portion of the study area (Fig. 1).

This angle of vision clearly reveals low resistivity values in the extreme SW of the block, in the same area of occurrence of high chargeability values. But, the low resistivity area is less encompassing, with low contrast values when compared with the chargeability area.

This probably occurs due to the extremely high resistivity values predominant in the area of volcanic tuff, around $550,000 \Omega . m$. The presence of disseminate sulfides proportion- 
ate a small decrease of the resistivity, sufficient enough to produce a contrast with the surrounding rock.

The perspective view from subsurface indicates high resistivity values along the whole base of the 3D block, correlating with low chargeability areas, which indicates the probable absence of mineralization beyond the volcanic tuff area, or otherwise, in the domain of a meta-conglomerate.

This region with high chargeability and low resistivity values is represented in the field by powder tuffs and lapilli tuffs which constitute the more elevated portions of the terrain, where field descriptions indicate impregnations of copper carbonates, such as malachite and azurite.

The data reveal a contrast of values between the main lithotypes of the area: low chargeability values for meta-conglomerates and andesites and high values for the volcanic tuffs. The low resistivity values at the surface reflect in large, the presence of sands partially or totally saturated, which gradually increase their thickness towards the NE.

\section{CONCLUSIONS}

The combined use of electrical resistivity and induced polarization geophysical methods, integrated with the geologic descriptions at surface and of drill cores, improved the knowledge of the mineral occurrence.

The Wenner-Schlumberger arrangement presented satisfactory results permitting to correlate the physical parameters of chargeability and resistivity, with the main lithotypes and mineralization present in the area. The radial layout of the survey lines allowed the generation of 3D models, and the integrated analysis of the measured physical parameter in various positions, besides the visualization of the lateral continuity of the mineralization.

The location of the mineral occurrences at the intersection of fault systems, suggests a structural control. Nevertheless, the predominance of elevated chargeability values and low resistivity values in the area of the volcanic tuffs indicate the presence of disseminated sulfides.

The fault system served probably as a preferred way for the hydrothermal fluids flow, in accordance with similar mineralization in the Camaquã Sedimentary Basin. The main genetic hypothesis for the copper mineralization in this basin area hydrothermal vein of magmatic origin, a porphyry copper type deposit or asyngenetic sedimentary model (Bettencourt, 1972; Santos \& Chaban, 1978; Licht, 1980; Altamirano, 1981; Beckel, 1990; Costa Filho, 1994).

In the case of the mineral occurrence studied, the access of fluids to high porosity lithotypes and the favorable condi- tions for cementation, possibly allowed the crystallization of disseminated sulfides in volcanic tuffs. The andesite and the metaconglomerate are rocks with very low porosity, which probably made impossible disseminated mineralization, except filling fractures.

The well description indicates levels of pyrite disseminated in fractures and pores and, chloritization, indicating a hydrothermal vein type mineralization, within a structurally controlled area with mineralization in fractures.

Metallogenic studies in the Camaquã Sedimentary Basin, during the last 40 years, suggest the alternative genesis of a disseminated copper type deposit. This hypothesis justified new geophysical programs, that resulted in the suggestion of a substantially larger mineralized area, indicating the potential for new confirmatory investigations.

\section{REFERENCES}

ALTAMIRANO JAF. 1981. Contribuição à gênese das ocorrências cupríferas estratiformes do Cerro dos Martins, RS. Porto Alegre, Master dissertation on Geosciences, Instituto de Geociências, Universidade Federal do Rio Grande do Sul. 172 pp.

BECKEL J. 1990. Metalogenía del Cu, Pb y Zn en la Cuenca de Camaquã durante el Ciclo Orogénico Brasiliano-Río Grande del Sur (Brasil). Barcelona, Doctorate thesis on Geosciences, Universidade de Salamanca. $275 \mathrm{pp}$.

BETTENCOURT JS. 1972. A Mina de cobre de Camaquã, Rio Grande do Sul. Porto Alegre, Doctorate thesis on Geosciences, Instituto de Geociências, Universidade Federal do Rio Grande do Sul. 342 pp.

BOCCHI PR. 1965. Relatório da Ocorrência Cuprífera de Colônia de Santa Bárbara. Brasil. Rio de Janeiro: DNPM, Divisão de Fomento da Produção Mineral. 76 pp.

BORBA AW. 2006. Evolução Geológica da "Bacia do Camaquã" (Neoproterozóico e Paleozóico inferior do Escudo Sul-Rio-Grandense, RS, Brasil): uma visão com base na integração de ferramentas de estratigrafia, petrografia e geologia isotópica. Porto Alegre, Doctorate thesis on Geosciences, Instituto de Geociências, Universidade Federal do Rio Grande do Sul. 121 pp.

CHEMALE Jr F. 2000. Evolução geológica do escudo Sul-Rio-Grandense. In: HOLZ M \& DE ROS LF (Eds.). Geologia do Rio Grande do Sul. Porto Alegre, Editora UFGRS. 522 pp.

COSTA FILHO JH. 1994. Prospecção das minas de cobre de Camaquã, Rio Grande do Sul. DNPM. Ministério da Agricultura. Boletim, 59: 1394.

DEGROOT-HEDLIN C \& CONSTABLE S. 1990. Occam's inversion to generate smooth, two-dimensional models form magnetotelluric data. Geophysics, 55: 1613-1624. 
EDWARDS LS. 1977. A modified pseudosection for resistivity and induced polarization. Geophysics, 42: 1020-1036.

KAZMIERCZAK TS. 2006. Mapeamento da Bacia do Camaquã com a utilização de dados geofísicos, geologia e sensoriamento remoto. Porto Alegre, Master dissertation on Geosciences, Instituto de Geociências, Universidade Federal do Rio Grande do Sul. 110 pp.

LICHT OAB. 1980. A descoberta da Jazida Santa Maria (Zn, Cu, Pb), Rio Grande do Sul - um caso histórico de prospecção geoquímica. In: Simpósio Brasileiro de Geoquímica, 1: 1980, Camboriú, Proceedings... Camboriú: SBGq, v. 1. p. 141.

LOKE MH \& BARKER RD. 1996. Rapid least-squares inversion of apparent resistivity pseudosections by a quasi-Newton method. Geophysical Prospecting, 44: 131-152.

MARANHÃO RJL. 1985. Introdução à Pesquisa Mineral. Banco do Nordeste do Brasil, Fortaleza, $2^{\text {nd }}$ ed., 796 pp.

NARDI LVS \& LIMA EF. 1985. A Associação Shoshonítica de Lavras do Sul, RS. Revista Brasileira de Geociências, 15(2): 139-146.

ORELLANA E. 1972. Prospección Geoeléctrica en Corriente Continua. Paraninfo, Madri. 523 pp.

PAIM PSG, CHEMALE Jr F \& LOPES RC. 2000. A Bacia do Camaquã. In: HOLZ M \& DE ROS LF (Eds.). Geologia do Rio Grande do Sul. Porto Alegre, Editora UFGRS. 522 pp.

PEREIRA RM. 2003. Fundamentos de Prospecção Mineral. Editora Interciência. 167 pp.

PETERS WC. 1978. Exploration and Mining Geology. John Wiley \& Sons, New York. 696 pp.
PORCHER CA. 1995. Programa Levantamentos Geológicos Básicos do Brasil. Folha Passo do Salsinho, Folha SH.22-Y-A-I-4. Estado do Rio Grande do Sul. Escala 1:50.000. Brasília, CPRM. 358 pp.

PORCHER CA \& LOPES RC. 2000. Programa Levantamentos Geológicos Básicos do Brasil. Folha Cachoeira, Folha SH.22-Y-A. Estado do Rio Grande do Sul. Escala 1:250.000. Brasília, CPRM. 117 pp.

RIBEIRO M. 1970. Geologia da Folha de Bom Jardim, Rio Grande do Sul, Brasil. Rio de Janeiro: DNPM, Boletim 2.

RIBEIRO M \& FANTINEL LMA. 1978. Associações Petrotectônicas do Escudo Sul-Rio-Grandense. I - tabulação e distribuição das associações petrotectônicas do escudo do Rio Grande do Sul. Iheringia, Série Geológica, v. 5, p. 19-54.

RONCHI LH \& LOBATO AOC. 2000. Minas do Camaquã, um estudo multidisciplinar. São Leopoldo: Unisinos. 366 pp.

SANTOS JF \& CHABAN N. 1978. Concentrações de cobre sedimentar do tipo red-bed em Caçapava do Sul (RS). In: Congresso Brasileiro de Geologia, 30: 1978, Proceedings... Recife: SBG, v. 6, p. 2562-2575.

SCHWEIG C. 2010. Caracterização geoelétrica da ocorrência de Cobre Colônia de Santa Bárbara, Município de Caçapava do Sul (RS). Caçapava do Sul, Monograph (Graduate in Geophysics), Universidade Federal do Pampa. 77 pp.

SUMNER JS. 1976. Principles of induced polarization for geophysical exploration. Amsterdam, Elsevier Scientific. 277 pp.

TELFORD WM, GELDART LP \& SHERIFF RE. 1990. Applied Geophysics. $2^{\text {nd }}$ ed., Cambridge University Press, New York. 774 pp.

\section{NOTES ABOUT THE AUTHORS}

César Augusto Moreira. Bachelor in Geology at Universidade Estadual Paulista - UNESP/Rio Claro-SP (2003). Worked as mining geologist at the São Francisco Mine (Serra da Borda Mineração e Metalurgia - SBMM - Yamana Gold). Doctor in Geosciences at Universidade Estadual Paulista - UNESP/Rio Claro-SP (2009). Associate professor in undergraduate courses of Geophysics and Geology at the Universidade Federal do Pampa - UNIPAMPA/Caçapava do Sul-RS (2009-2011). Presently assistant professor at the Department of Applied Geology, Universidade Estadual Paulista - UNESP/Rio Claro-SP. Areas of activity: applied geophysics, mineral research, hydrogeology and environmental studies.

Syngra Machado Lopes. Bachelor in Geophysics at Universidade Federal do Pampa - UNIPAMPA/Caçapava do Sul-RS. M.Sc. graduate student in Geosciences, with emphasis in Regional Geology, at Universidade Estadual Paulista - UNESP/Rio Claro-SP. Areas of interest: Mineral geophysical prospecting.

Camila Schweig. Bachelor in Geophysics at Universidade Federal do Pampa - UNIPAMPA/Caçapava do Sul-RS. M.Sc. graduate student in Geosciences, with emphasis on Regional Geology, at Universidade Estadual Paulista - UNESP/Rio Claro-SP. Areas of interest: geophysical characterization of sedimentary basins.

Adriano da Rosa Seixas. Bachelor in Geophysics at Universidade Federal do Pampa - UNIPAMPA/Caçapava do Sul-RS. M.Sc. graduate student in Geosciences, with emphasis on Regional Geology, at Universidade Estadual Paulista - UNESP/Rio Claro-SP. Areas of interest: mineral geophysical prospection. 